\author{
Hanna SOMMER ${ }^{1}$ \\ Grzegorz ZAKRZEWSKI ${ }^{2}$
}
"The world has enough for everyone's need, but not enough for everyone's greed".

Mahatma Gandhi

\title{
ECOLOGICAL SECURITY VS. FOOD SECURITY
}

This article attempts to indicate the relationship between some of the most important issues concerning the global population, namely ecological factors and food security. While "exploiting" the Earth, man has violated its natural cycle and, in many respects, pushed many ecological systems to the ultimate environmental threshold. Today, due to the industrial use of the natural environment, its shaping and protection is subject of numerous discussions. If a given ecosystem has been degraded, it is the task of humankind to restore it. Bioethicists investigate how deep this interference could be when modifying the world of fauna and flora. Often, however, those simple farming methods, already known and used in medieval agriculture, are sufficient. The aim of the study is to explore the opinions of young inhabitants of Podkarpacie (also known as Subcarpathian Province) on food security assessed through the prism of ecological security issues in the context of a total ban on cod fishing in the Baltic Sea. The ban was introduced for four years from January 2020 and, while the initiative may contribute to the renewal of the cod population, it is highly restrictive and covers about 150 fishing vessels, the owners of which have no other income.

Keywords: ecological security, food security, cod fishing ban.

\section{INTRODUCTION}

Nature has given humankind access to food, clean waters, uncontaminated soil and photosynthesis, perfectly describing the flow of energy in ecosystems (See more: Sommer, Zakrzewski 2018). Nature generates ecosystem services for itself -services which man has started to use imprudently. Our existence depends on the continuous supply of ecosystem services in both quantitative and qualitative sense. These goods, widely available to man, have not been seen as valuable so far and being public goods, they have not been a market product, since how could one appraise the value of clean air or water. There are no problems

\footnotetext{
${ }^{1}$ Hanna Sommer, PhD, Associate Professor, Department of Humanities and Social Sciences, Faculty of Management, Rzeszów University of Technology, Al. Powstańców Warszawy 8, 35-959 Rzeszów; e-mail: hansom@prz.edu.pl (corresponding author). ORCID: 0000-0001-7208-7641.

${ }^{2}$ Grzegorz Zakrzewski, PhD, Eng., University of Security in Poznań, ul. Marynarki Polskiej 15, 80-557 Gdańsk; e-mail: grzegorz.zakrzewski@wsb.net.pl. ORCID: 0000-0002-0945-5322.
} 
with establishing the cost of atmospheric emissions, however, or fees for the economic use of water. The consequence of such actions is the degradation of ecosystems and decreasing biodiversity. We are approaching the ultimate environmental thresholds, suffering painful consequences thereof. On the example of the Baltic Sea, in the areas where total ban on fishing the Baltic cod (Gadus morhua callarias), has been in force since 1 January 2020 the feelings of the selected social group regarding food security will be examined through the prism of ecological security issues.

\section{BIOLOGICAL DIVERSITY, ECOSYSTEMS AND HUMAN WELFARE}

The global economy which governs the modern world exerts an ever-increasing influence on the functioning of ecosystems. Protection and rational, scientifically based, shaping of the environment are now recognized as the main task of decision-makers. The concept of ecosystem was introduced in 1935 by Arthur George Tansley, an English botanist as the basic functional and spatial unit, which is formed by two components remaining closely related to each other:

- inanimate one (biotope, also called habitat), which consists of soil, water and air with their physicochemical properties, as well as climate;

- animate one (biocenosis), consisting of a combination of species specific to a given biotope under certain geographical conditions (See more: Sommer, Zakrzewski, 2017a).

Throughout the era of the human civilisation which left written records, a man had a minimal impact on their environment. Local effects in the environment were so small that the environment was able to regenerate - restore its resources. The resistance of the natural environment has been exposed by man to the limits of its capabilities.

Many ecological systems have already reached the ultimate environmental threshold. Crossing this border may lead to a catastrophe, as it triggers a chain reaction leading to the irreversible destruction of this environment or its basic elements (Borsuk, 1994).

The condition of the environment and the state of its endangerment directly affect ecological security (Sałek-Imińska, 2017).

Fig. 1 presents a simplified ecosystem for the needs of the article.

The ultimate environmental thresholds (UET) are presented in Fig. 2.

Jerzy Kozłowski distinguishes four categories of UET as they allow defining the final boundaries of the location, scale, type and time of individual development actions carried out in a given area, and thus to designate an ecologically safe solutions space in which these actions must be maintained (Kozłowski, 2011).

Universal security includes many measures to the extent necessary for human survival as a result of human actions or natural forces which threaten protected values (Karwan, 2019). The contemporary man exploits the natural environment across borders not only by introducing local, continental and global air pollution. These pollutants do not respect the physical borders of countries. Earth is a planet whose surface is covered by land in only about $25 \%$. The remaining part is covered by the global ocean. It is the largest ecosystem in the world, whose resources are used not only by the coastal states. 


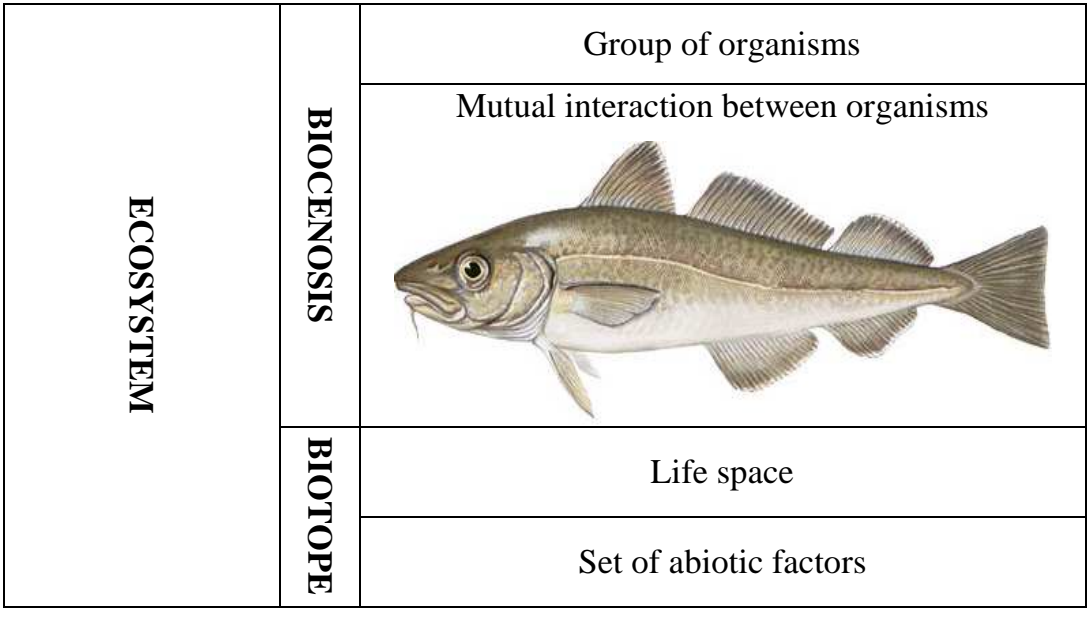

Fig. 1. Simplified ecosystem

Source: Own data.

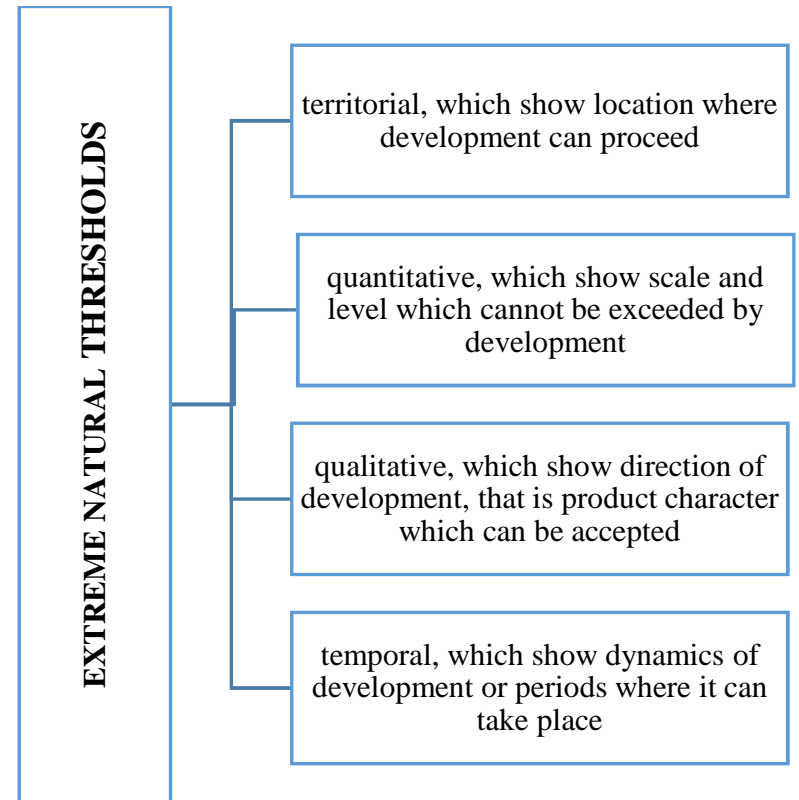

Fig. 2. Method of extreme natural thresholds

Source: Own research based on (Kozłowski, 2011). 


\section{ECONOMICS OF ECOSYSTEM AND BIODIVERSITY OF THE BALTIC SEA IN THE ASPECT OF INTRODUCING FISHING QUOTAS IN THE EUROPEAN UNION}

Scientists are divided in their establishment of what caused the catastrophe in the Baltic cod population. Some of them blame mass fishing for this situation, while others indicate climate change and the lack of substantial winter saltwater inflows from the North Sea. Everyone is convinced that the main reason may be the increase in pollution and biogenicity caused by the intensive agriculture of the countries lying in the catchment area.

The International Council for the Exploration of the Sea (ICES) announced on 29 May 2019 the latest results of the study on the state of the stocks of the basic fish species exploited in the Baltic Sea and made recommendations on the size of fishing quotas in 2020 (ICES, 2019) Currently, the spawning stock biomass is one of the lowest, and the exploitable stock biomass (approximately fish $\geq 35 \mathrm{~cm}$ ) is the lowest in the history of this stock assessment.

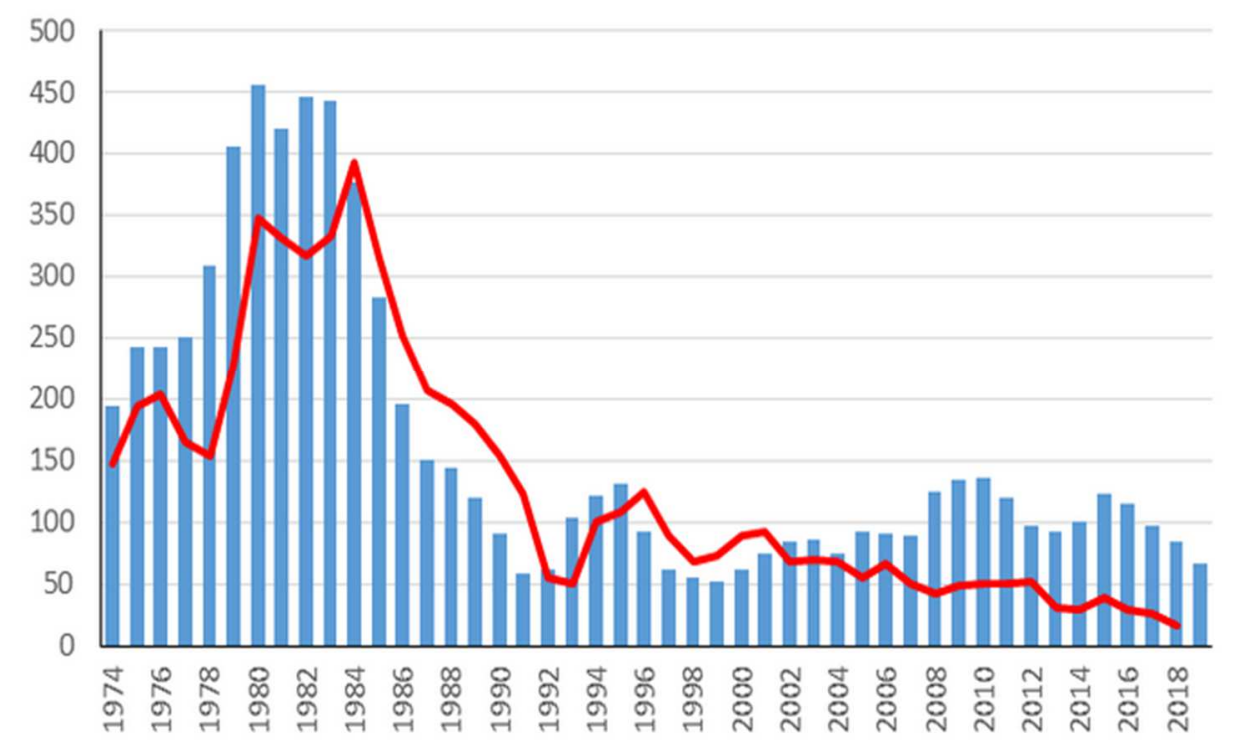

Chart 1. Cargo and biomass of breeding shoal (thousands of tons) East Baltic cods in years 1974-2019

Source: (MIR-PIB Gdynia, 2020).

All of the determined objectives and directions of activities and tasks are the basis for the implementation of environmental policy (Puacz-Olszewska, 2017), which defines an action plan aimed at improving the quality of ecological and food security in the Baltic Sea area. One of the most important tasks of the Republic of Poland is to ensure environmental protection (Jurgilewicz, M., Jurgilewicz, O., 2019).

ICES recommends suspension of cod fishing in 2020, based on the precautionary principle (National Marine Fisheries Research Institute, 2020). The European Commission has introduced a complete ban on cod fishing in the Baltic Sea from 1 January 2020 to 2024. 
This period of time is intended to ensure the recovery of the Baltic cod stocks. The goal of restoring biodiversity is likely to be achieved. It will be possible to assess the extent of this achievement on the basis of the population study in 2024 and mid-year studies.

The introduced ban on fishing has generated associated costs, which include:

- unavailability of the Baltic cod on the market, partly replaced by the Atlantic cod;

- reduced income of the fishing industry;

- exclusion of the ship owners of sports and recreational vessels from the programme mitigating the socio-economic effects thereof.

In the ports of the Polish coast there are about 200 (out of which 150 are active) vessels which can carry from several to 20 or more anglers depending on the craft (Lis, 2019) The situation is made all the more dubiously spicy by the fact that, according to the data of the National Marine Fisheries Research Institute, their industry caught only 1-2\% of the annual quota of this species allocated to mass fishing. In order to survive this difficult period, ship owners operate additional activities such as room rental and fishing equipment retail shops.

\section{METHODOLOGY AND ANALYSIS OF THE AUTHOR'S ORIGINAL RESEARCH}

The research methodology is a set of rules, stating who, what and where is to be studied. The key to the reliable measurement of the phenomenon being of interest to us is in the selection of the right research method in order to measure the phenomenon under study in the best way possible. A method is a conscious and consistent course of action, which leads to the achievement of a specific research objective, which should constitute a research problem, expressed by a relevant question or a set of questions the answers to which the research undertaken ought to provide. In this study, the research problem has been formulated as follows: What are the attitudes of the UR students majoring in such fields as biology, protection of environment and agriculture towards the issues related to food security assessed through the prism of ecological security issues?

The research problem, as a fundamental component of any significant research, is a complex component, hence detailed questions are needed to clarify it.

- Do the actions of the European Commission imposing a total ban on cod fishing ensure the recovery of biodiversity in the Baltic Sea?

- Does ecological security have an impact on food security?

- How is the wealth of the ecosystem understood in terms of food efficiency?

- What is the attitude towards the industrial-scale fish farming (e.g. Norwegian salmon) and seafood?

- Should sports (recreational) sea fishing be prohibited?

Research hypotheses should be derived from the research problem and specific questions.

- Maintaining a healthy environment and production using ecological methods exerts the most beneficial impact on the health of both people and animals and the entire natural environment.

- A complete ban on cod fishing may considerably contribute to improving the biodiversity in the Baltic sea.

- Environmental security has an immense impact on food security. 
- In the long-term perspective, maintaining well-functioning ecosystems is the most cost-effective and, in some cases, the only solution leading to the satisfaction of human needs.

- Fish and seafood production on an industrial scale gains a positive assessment.

- Sports (recreational) sea fishing should not be prohibited due to minute quantities of fish caught, while providing livelihood for around 200 ship owners and associated staff.

Most methodologists consider it necessary to formulate hypotheses in the course of the research, hence each scientific study should consist of three successive stages:

- detecting and determining the research problem,

- formulating a hypothesis, which is a hypothetical solution to the problem,

- verifying the hypothesis (Konarzewski, 2000).

In the methodology of scientific research, an important function is performed by research techniques, which is practical measure, regulated by carefully developed indications, allowing for obtaining optimally verifiable information, opinions and facts.

A survey is a technique of collecting information, consisting in the completion of special questionnaires by respondents, generally with a high degree of standardisation in the presence or more often without the presence of an interviewer. A survey is, therefore, a technique for collecting quantitative data, and to a lesser extent - qualitative data.

A questionnaire consisting of 15 questions (5 open and 10 close-ended questions) was used for the research.

The research was conducted using the CAWI method (Computer Assisted Web Interviews) at the turn of April and May 2020 among the students of the University of Rzeszów in the fields of biology, environment protection and agriculture. The questionnaire was received by 150 people, however only 118 questionnaires were qualified for the analysis due to incomplete answers.

The young people, when asked about their attitude to ecology, resulting from their knowledge and sensitivity which influence pro-ecological attitudes, responded as follows (Chart 2).

Most of the respondents have a definitely positive attitude to ecology (66\%). Slightly fewer $(24 \%)$ have a rather positive and $10 \%$ neutral attitude. None of the interviewees gave a rather negative or definitely negative answer. Undoubtedly, the pro-ecological attitudes of the respondents are the result of acquiring knowledge and ecological sensitivity of a conscious human being, in this case students of biology, environment protection and agriculture.

In the next question, the respondents were asked to answer how they understood environmental security. The most frequent answers were: it is a desirable ecological condition; healthy existence of the ecosystem; nature. Many of the respondents pointed out that ecological security depends on the political system.

However, with respect to the question of how they understood food security, the following answers appeared:

- ensuring the right amount of food of a certain quality;

- guaranteeing individual people, the possibility of purchasing food which satisfy their nutritional requirements;

- efficient use of food;

- food storage in compliance with food safety rules; 
- ensuring that food is healthy; that it does not contain contaminants or substances harmful to humans;

- society should not allow any human being to starve;

- appropriate food distribution.

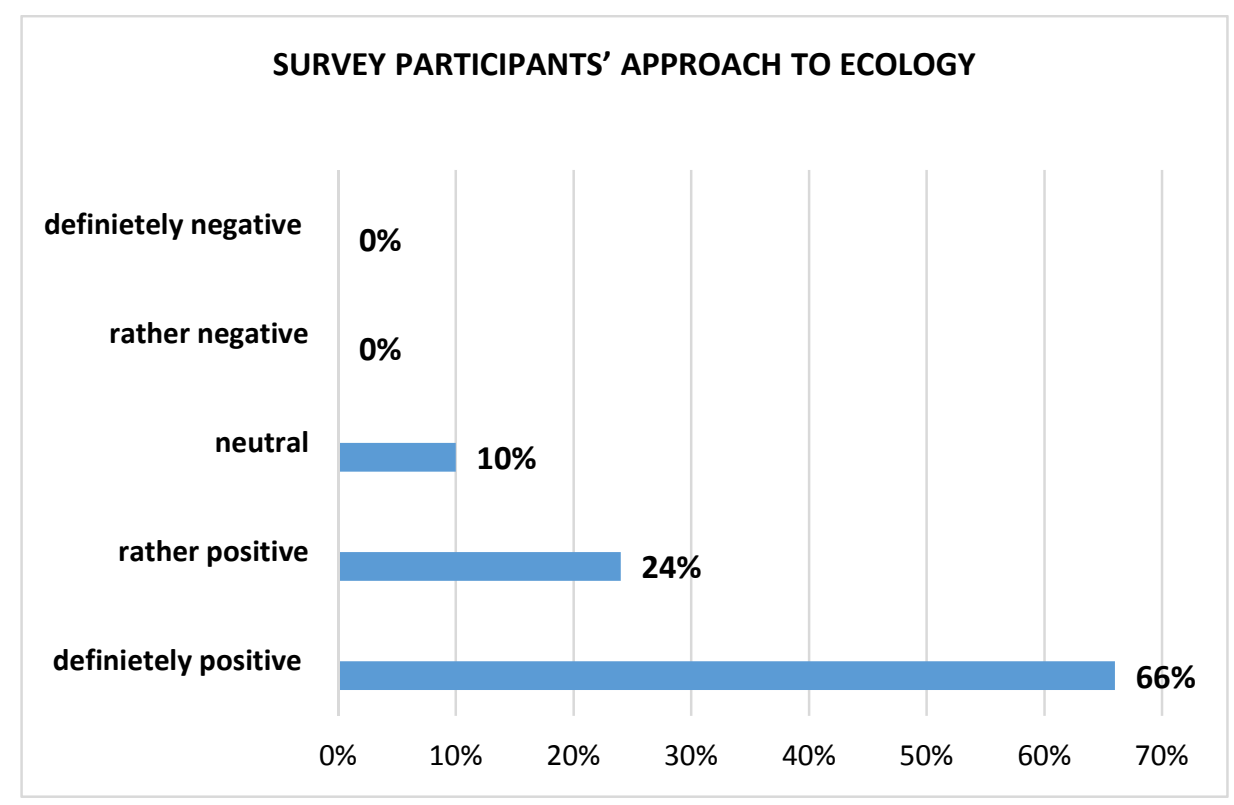

Chart 2. Survey participants' approach to ecology

Source: authors' own research.

When asked about how they understand the wealth of an ecosystem in terms of food efficiency (food production), the respondents were very willing to provide comprehensive information on this subject:

- Maintaining well-functioning ecosystems is the most cost-effective, and in some cases the only, solution to meet people's needs in the long term.

- Maintaining a healthy environment is also essential because there exists the so-called critical point, where, having reached it, the destroyed ecosystem will cease to provide services on which we depend.

- Understanding, exploring and estimating the value of ecosystem services is essential for good environmental management. It is also an obligation towards future generations.

- Global climate changes are the main threat to biodiversity.

- Agriculture conducted with eco-friendly methods has the most beneficial effect on both human and animal health as well as the entire natural environment.

- Each ecosystem creates a lot of diverse benefits, while valuation usually refers only to one or two of them. In addition, protection of the ecosystems indicates an infinite supply of their services, but not a one-off economic benefit. Therefore, in terms of long-term return on investment ecosystem services are unbeatable. 
The opinion on the industrialisation of food production held by the surveyed students is illustrated in Chart 3.

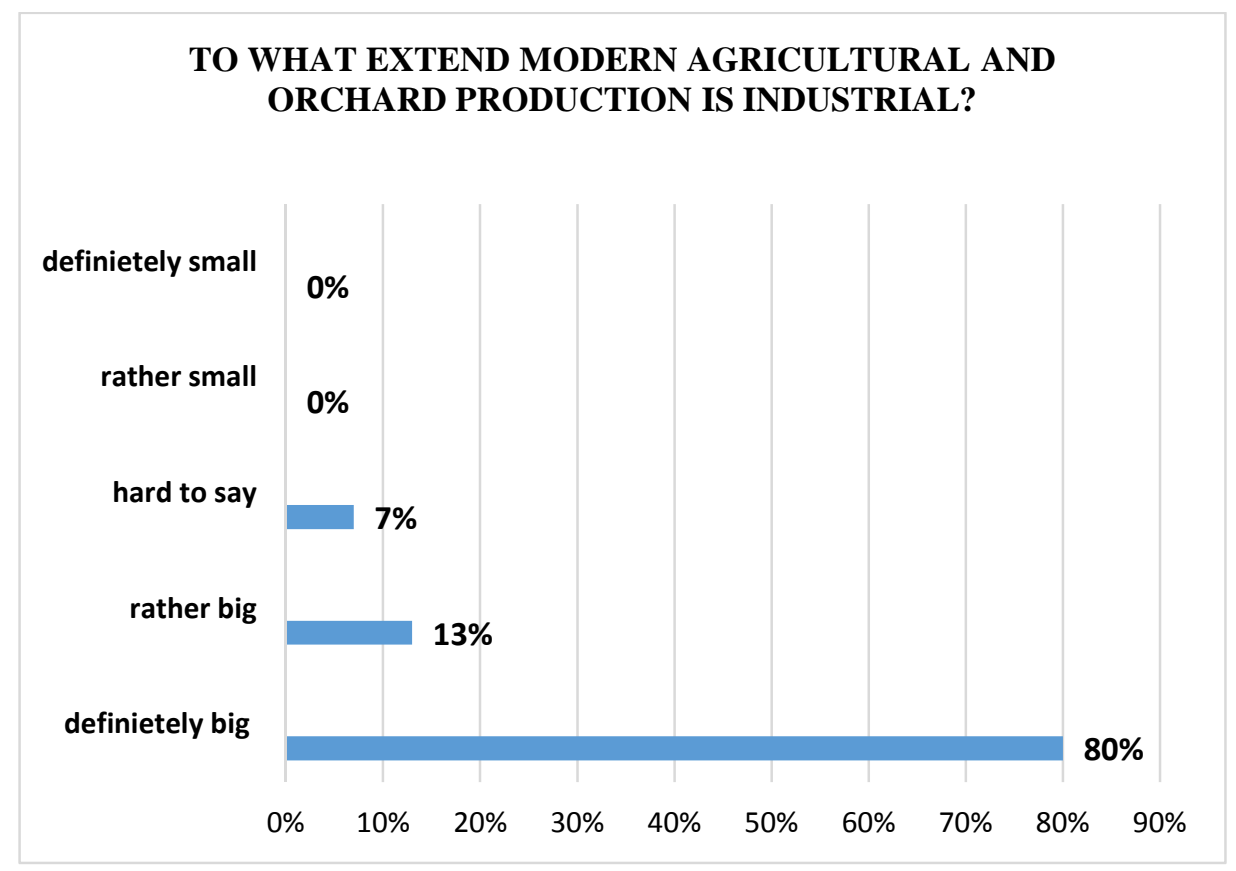

Chart 3. To what extend modern agricultural and orchard production is industrial?

Source: authors' own research.

In Chart 3, the unanimity among the respondents on the subject of assessing the degree of food production on an industrial scale may be surprising. As many as $80 \%$ of the respondents claim that such production takes place to a definitely large extent, $13 \%$ to a rather large extent, and $7 \%$ were unable to take a position on this issue. Concerning the respondents' previous statements, one may conclude that they are fully aware of the fact that large-scale food production is leading to immense changes in the ecosystem.

The vast majority of the respondents $(86 \%)$ are aware of the ban on cod fishing in the Baltic Sea. The issue of stating the period over which this prohibition is in force looks a little bit worse. It can be stated that few of these people can correctly specify the duration of this period. On the other hand, $14 \%$ of the respondents are not aware of the existence of such a ban. The source of their knowledge concerning the action the European Commission introducing a total ban on cod fishing in the Baltic Sea is the Internet and TV.

Are the surveyed students aware of the total ban on cod fishing in the Baltic Sea? The results of the research are presented in Chart 4.

Whether the respondents, young people living in Podkarpacie, show solidarity with the fishermen who lost their jobs due to the fishing ban, is shown in Chart 5. 


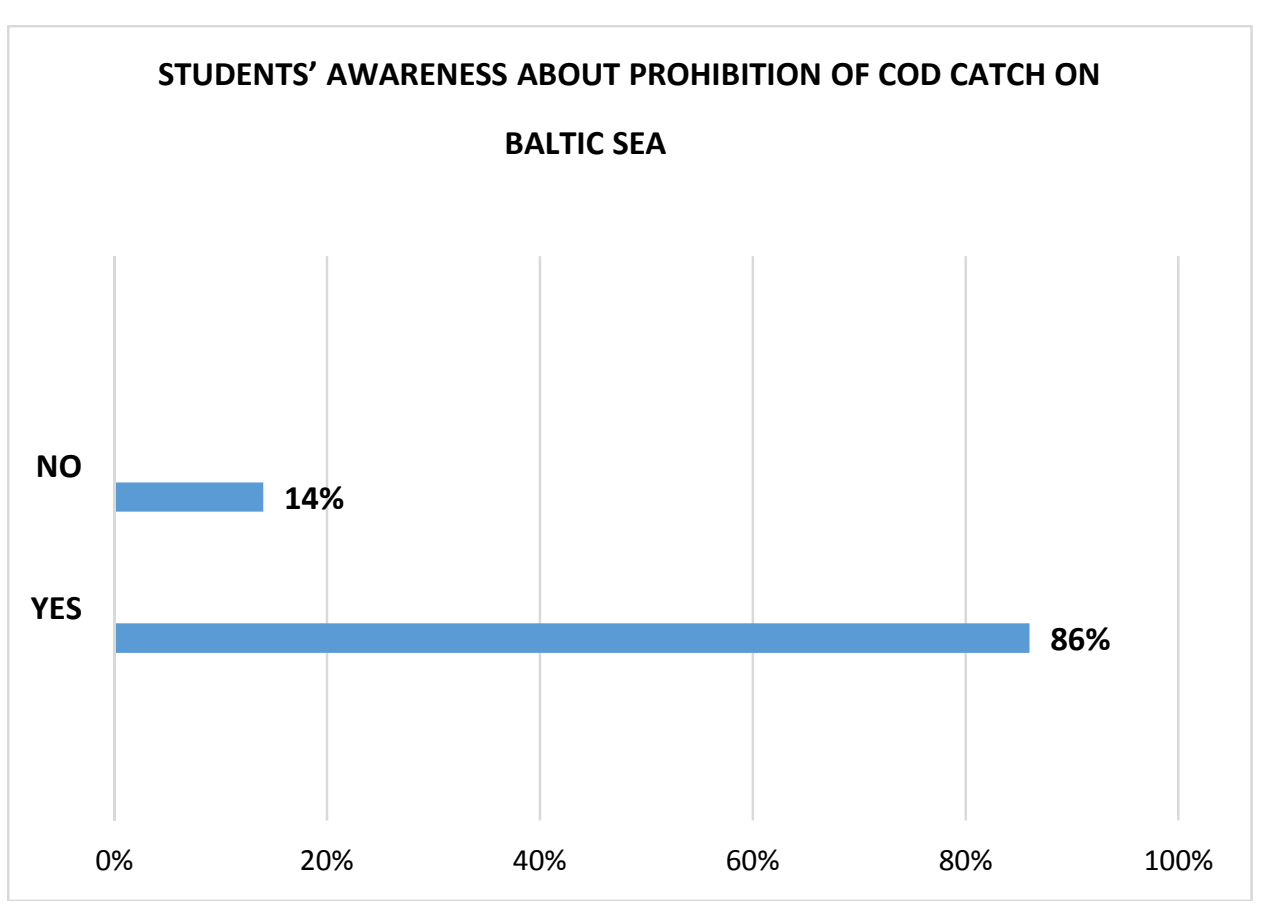

Chart 4. Awareness of prohibition of cod catch on Baltic sea among survey participants Source: authors' own research.

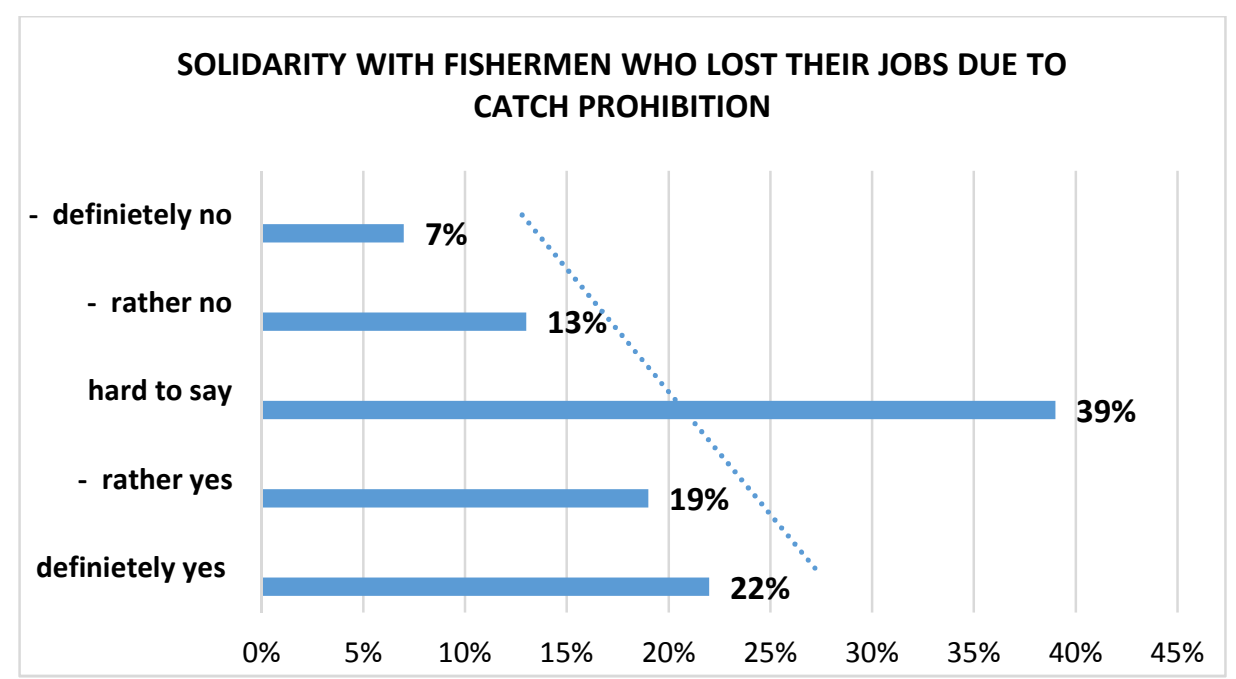

Chart 5. Solidarity with fishermen who lost their jobs due to catch prohibition Source: authors' own research. 
In Chart 5, the majority of the respondents (39\%) are unable to take a stance with regard to solidarity with the fishermen who lost their jobs due to the ban on cod fishing in the Baltic Sea. In the remaining answers, one can draw a trendline, which indicates a certain pattern in the responses. Among the respondents, $22 \%$ show solidarity with the fishermen and $19 \%$ rather agree with it. On the other hand, $20 \%$ of respondents claim that the fishermen do not deserve the feeling of solidarity from other people in this matter, of which $7 \%$ take a definitely negative stance in this case. It can be assumed that the large distance of the respondents' place of residence from the fishermen's place of work and residence could have had an impact on the results of the study.

The respondents also expressed their opinion on sport/recreational sea fishing. It is illustrated in Chart 6.

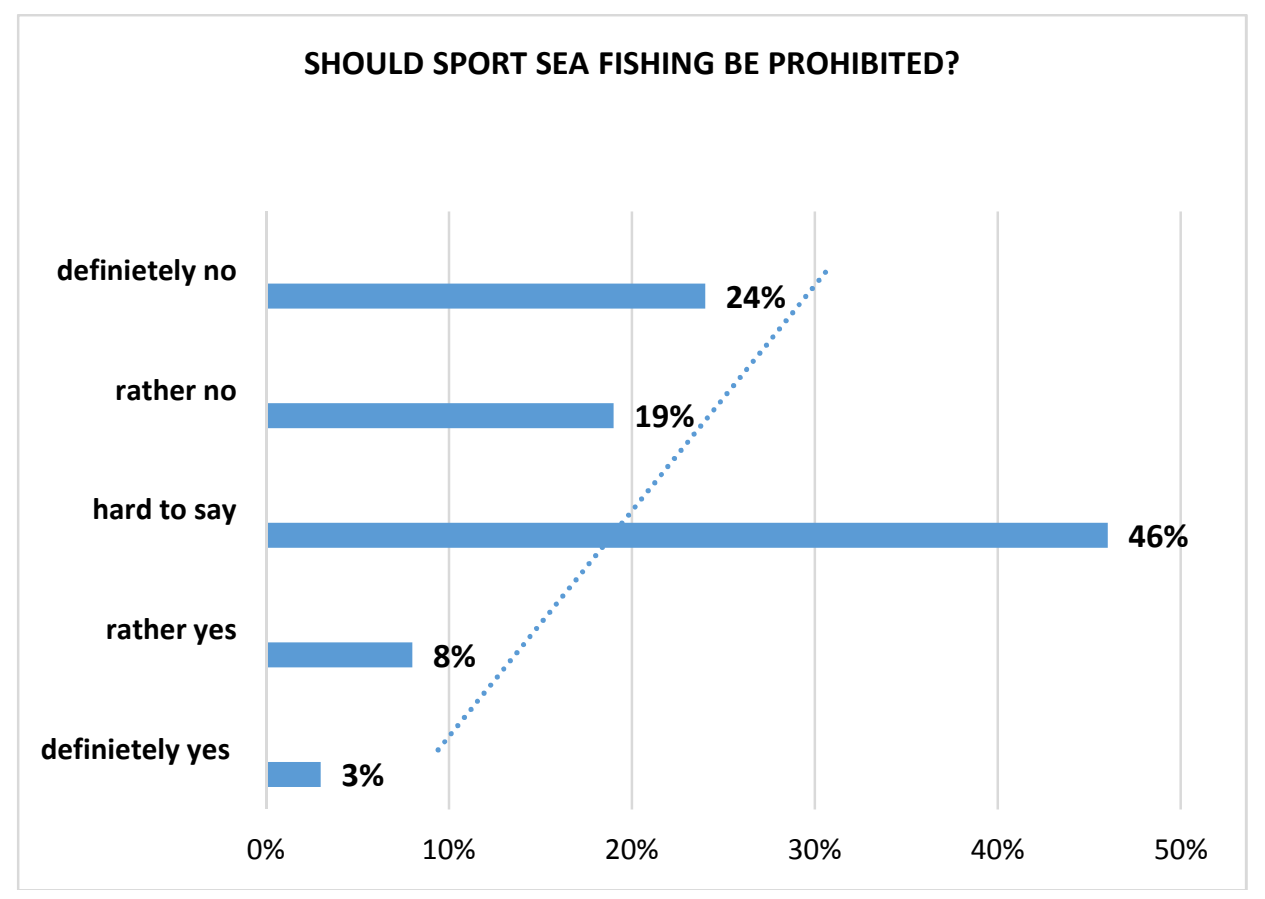

Chart 6. Should sport sea fishing be prohibited?

Source: authors' own research.

As many as $46 \%$ of the surveyed students were unable to take a position on the subject of recreational fishing. In the other responses, a trend line may be drawn, opposite to the one which indicates the solidarity with fishermen who lost their jobs due to the ban on fishing. 24\% of the respondents definitely do not oppose such fishing operations, and $19 \%$ rather support this opinion. On the other hand, $8 \%$ stated that such manner of fishing should rather be prohibited, and 3\% are firmly in favour of banning sea fishing in a sports form.

Another issue which the surveyed students were asked to voice their opinions about was the EU recommendation for a total ban on cod fishing. Will the European Commission's 
actions introducing a complete ban on cod fishing ensure the recovery of biodiversity in the Baltic Sea? The answers are presented in Chart 7.

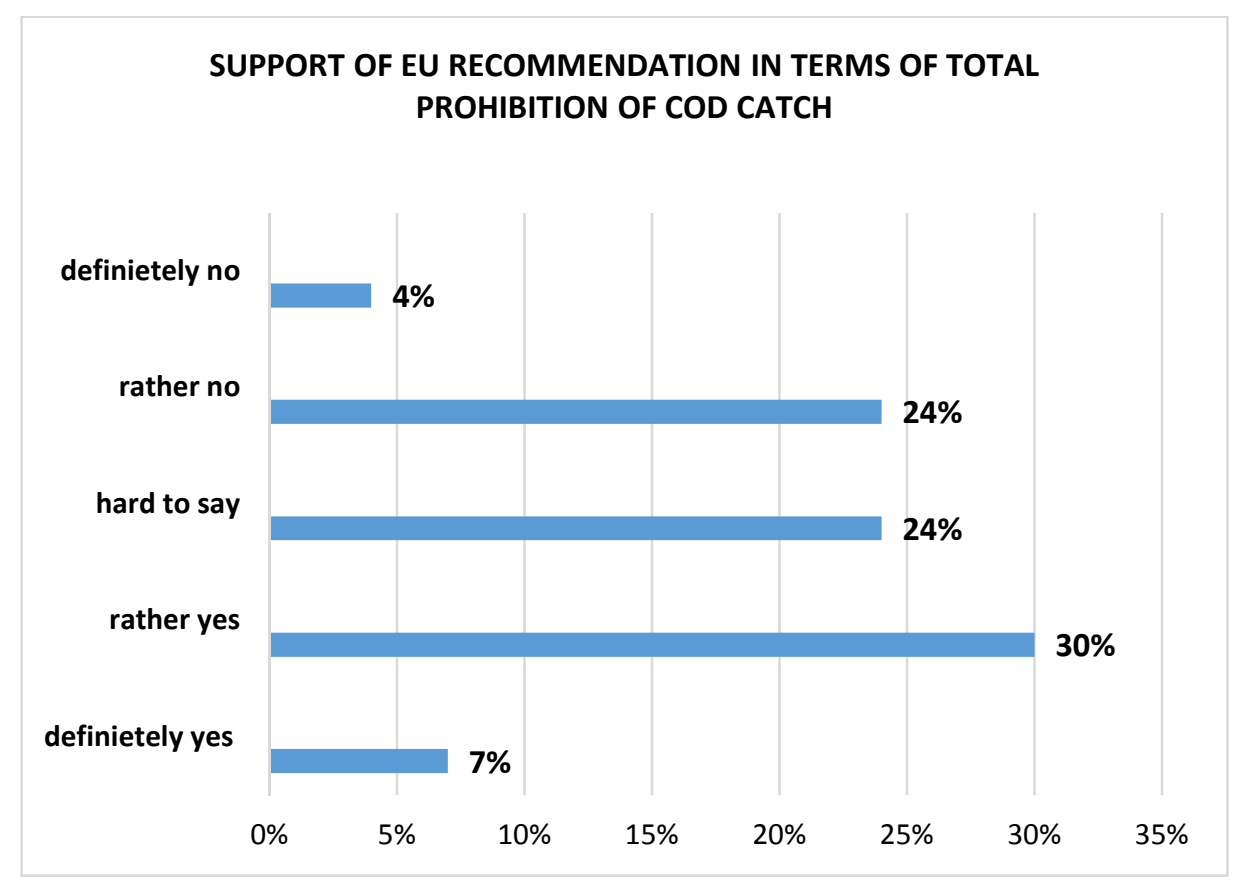

Chart 7. Support of EU recommendation in terms of total prohibition of cod catch

Source: authors' own research.

As many as $37 \%$ of respondents support the ban on cod fishing, of which $7 \%$ are definitely convinced. A high percentage (24\%) have no opinion on this issue and, by analogy, are not convinced about this ban, and $4 \%$ are firmly against it, claiming that a total ban on cod fishing will not ensure a restoration of biodiversity in the Baltic Sea.

The respondents were also asked about the extent to which maintaining a healthy environment leads to satisfying the existential needs of humans. Their opinions were presented in Chart 8.

Almost half of the respondents $(44 \%)$ are convinced that maintaining a healthy environment leads to satisfying the existential needs of humans, and $22 \%$ are aware of this fact. $15 \%$ of respondents cannot take a position on this issue. However, some respondents believe that a healthy environment is unlikely to satisfy (10\%) and definitely will not satisfy (9\%) existential human needs. According to the responses to this topic, one can see a trendline depicting the growing number of indications supporting the importance of a healthy environment.

The young people participating in the survey were also asked to answer the question of whether ecological security has an impact on food security. The opinions were included in Chart 9. 


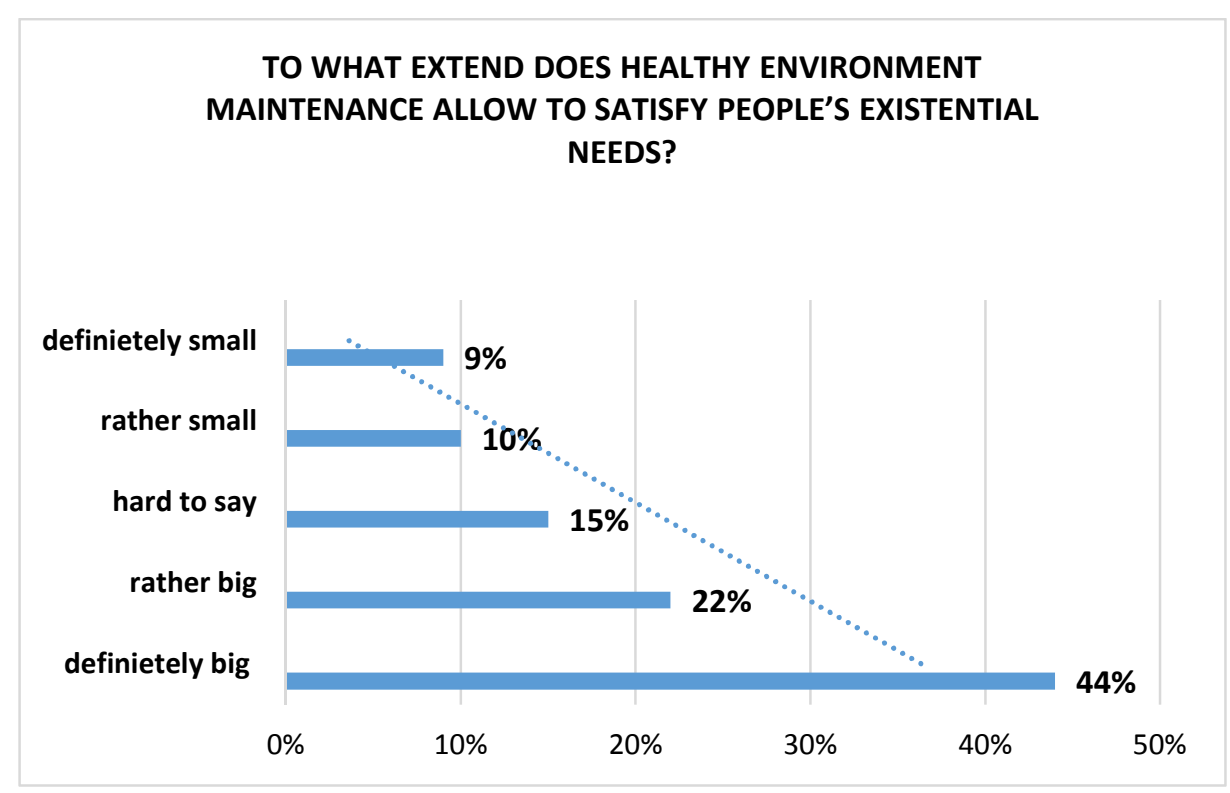

Chart 8 . To what extend does healthy environment maintenance allow to satisfy people's existential needs?

Source: authors' own research.

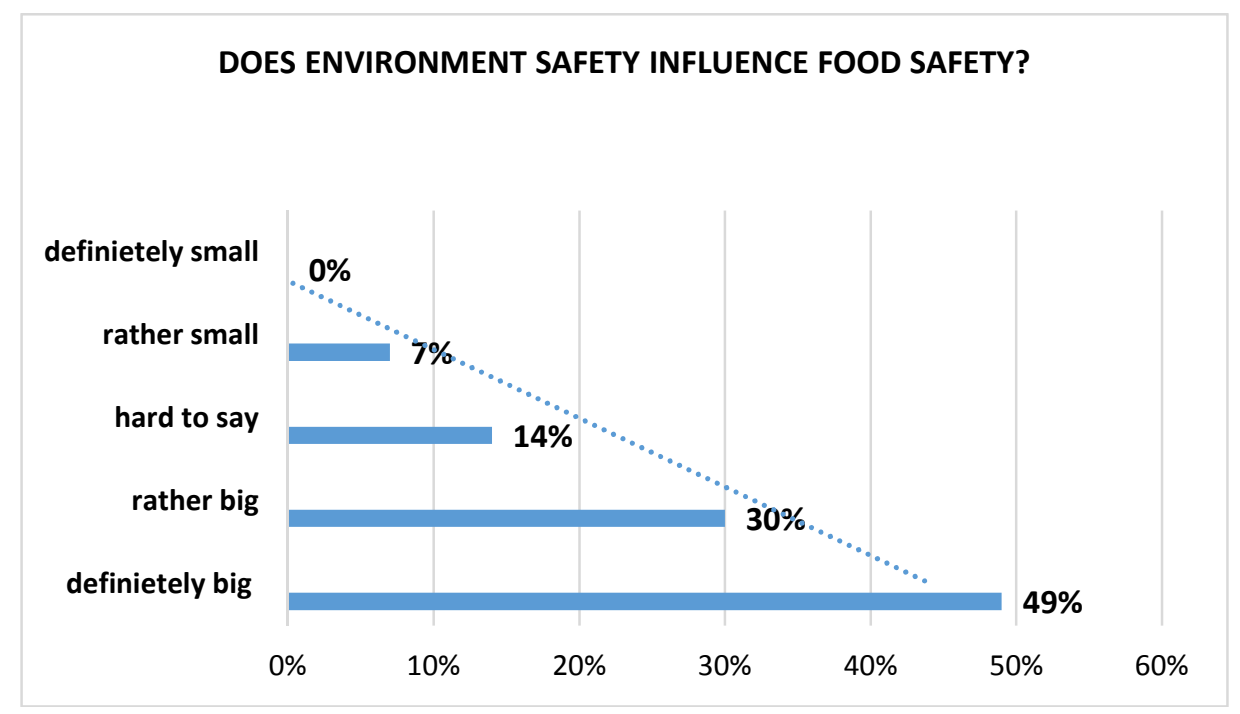

Chart 9. Does environment safety influence food safety Source: authors' own research

Source: authors' own research. 
Young inhabitants of Podkarpacie believe that ecological security has a definite (49\%) and considerable (30\%) impact on food security. $14 \%$ of respondents have no opinion on this subject, and 7\% described the degree of impact as low. None of the respondents strongly negated the occurrence of such an impact.

The graph shows a noticeable growing trendline of the respondents' replies, from the lack of a decisive impact of ecological behaviours on food security to a marked influence thereof.

Summing up the results of the conducted research in the context of verifying the hypotheses postulated, it should be concluded that the assumed hypotheses proved correct to a lesser or greater extent.

The vast majority of the respondents are convinced that maintaining a healthy environment leads to satisfying the existential needs of humans, while being simultaneously aware that the production using ecological methods has an impact on human and animal health and the entire natural environment.

Nearly $40 \%$ of respondents were in favour of the total ban on cod fishing in the Baltic Sea; $24 \%$ were unable to define their position clearly on this subject, and fewer than $30 \%$ claimed that a total ban on cod fishing would not ensure the restoration of biodiversity in the Baltic Sea.

Almost $80 \%$ of respondents stated that ecological safety has a huge impact on food security, $14 \%$ were unable to assess this dependence, and $7 \%$ considered that this impact is low.

The respondents believed that well-functioning ecosystems are the most cost-effective solution leading to satisfying human nutritional needs in the long run. According to their assessment, food production is currently taking place on an industrial scale, which is leading to huge changes in the ecosystem.

With respect to the issue of sports (recreational) sea fishing, as many as $46 \%$ of respondents did not take a position. Over $40 \%$ of respondents support this form of fishing, and only $11 \%$ are against recreational fishing. Such a large percentage of people who did not take a position on the analysed issue may stem from the poor knowledge of the topic. This form of fishing constitutes a minute fraction of the quantity of the fish caught and provides the livelihood for about two hundred owners of vessels and associated staff (e.g. hotels, specialist fishing equipment stores). Here, a warning should be given against the effect of throwing out the baby with the bathwater (See more: https://biznes.trojmiasto.pl/ Protest-rybakow-Tym-razem-podrzucono-ryby-pod-brame-Urzedu-Morskiegon144938.html).

\section{CONCLUSIONS}

Food security is one of the basic human needs, which, in simple terms, through the prism of Maslow's pyramid of needs (Sommer, Zakrzewski, 2017), boils down to the necessity of ensuring continuous access to food supplies. Therefore, it also refers to the avoidance of famine and a sense of security.

The improvement of the Baltic Sea environment is a problem to which solutions are being sought also by Poland. The restoration of the Baltic cod species, is an important issue which would ensure stable and healthy fish populations which would not only be capable of providing food for consumers and jobs in the fisheries sector but would also contribute to increasing the resilience of the Baltic Sea ecosystem to the negative effects of the 
observed climate change. Environmental degradation may lead to ecological disasters on a local or global scale.

The Baltic cod has not been able to revive itself for years. The poor condition of the species or the lack of the appearance of this fish in the coastal zone is a serious problem which environmentalists have been pointing to for a considerable period of time. Limitation of fishing is expected to give the fish a chance to recover. However, for the first time in the fishing history, recreational fishermen were banned from fishing for cod. The ban on catching fish with a fishing rod from a boat was introduced for at least four years from 1 January 2020.

The initiatives regarding the maintenance of food safety, carried out at both regional and global level, testify to the increasing need for preventive and corrective actions in this area witnessing progressive degradation of the natural environment. The introduced restrictions should be carefully monitored and investigated as future solutions interfering with the natural environment of man in order to obtain a clear answer to the question of whether aquaculture will be the main solution to avoid a disaster lurking in the future to the detriment of the Earth's inhabitants - famine.

It is however still necessary to consider whether taking away jobs from the recreational fishermen who catch negligible quantities of fish will have a significant impact on improving the ecosystem of the Baltic Sea.

\section{REFERENCES}

Borsuk, S., red. (1994). Ochrona i ksztattowanie środowiska. Toruń-Bydgoszcz.

Chudziński, T. (2019). Battyk stat się nieprzyjazny dla dorsza. Dlaczego zaczą obowiazywać zakaz połowu tej ryby?. „Dzziennik Bałtycki” 29.11.2019 r. [Access: 05.04.2020]. Access on the internet: https://dziennikbaltycki.pl/baltyk-stal-sie-nieprzyjazny-dla-dorsza-dlaczegozaczal-obowiazywac-zakaz-polowu-tej-ryby/ar/c3-14616463.

https://biznes.trojmiasto.pl/Protest-rybakow-Tym-razem-podrzucono-ryby-pod-brame-UrzeduMorskiego-n144938.html [Access: 05.04.2020].

https://www.kalendarzrolnikow.pl/1954/plodozmian-czyli-rotacja-roslin-system-dwupolowy-isystem-trzypolowy [Access: 05.04.2020].

Jurgilewicz, M., Jurgilewicz, O. (2019). Management of information security and its protection in criminal matters: case of Poland. "Journal of Security and Sustainability", Vol. 8(3), March. Karwan, H.M. (2019). Bezpieczeństwo publiczne a koncepcja umowy społecznej [w:] Gałecki, A., red., W trosce o bezpieczne jutro. Reminiscencje i zamierzenia. Poznań: Wydawnictwo WSB. Konarzewski, K. (2000). Jak uprawiać badania pedagogiczne? Metodologia praktyczna. Warszawa: WSiP.

Kozłowski, J. (2011). Podejście ekologiczne w metodyce planowania. Metoda krańcowych progów przyrodniczych, „Problemy Rozwoju Miast”, No. 1-2 [Access: 05.04.2020]. Access on the internet: http://yadda.icm.edu.pl/yadda/element/bwmeta1.element.desklight-84b5f76be42c-47d0-a740-f8591b4bc0e6.

Lis, M. (2019). Poptynątem na dorsze. To jeden z ostatnich rejsów [Access: 07.04.2020. Access on the internet: https://finanse.wp.pl/poplynalem-na-dorsze-to-jeden-z-ostatnich-rejsow6451241617205377a.

Morski Instytut Rybacki (MIR) Komunikat o stanie zasobów ryb Battyku i zalecanych przez ICES wielkości kwot połowowych w roku 2020 [Access: 7.04.2020]. Access on the internet: 
https://mir.gdynia.pl/komunikat-o-stanie-zasobow-ryb-baltyku-i-zalecanych-przez-iceswielkosci-kwot-polowowych-w-roku-2020/.

Puacz-Olszewska, J., Bezpieczeństwo i ochrona środowiska naturalnego przy gospodarowaniu odpadami komunalnymi - zasady prawne, Zeszyty Naukowe Wyższej Szkoły Informatyki, Zarządzania I Administracji, Rzeszów 2017, t. 15, z. 2(39).

Sałek-Imińska, A. (2017). Ekonomiczne narzędzia zarzadzania przedsiębiorstwem w zakresie bezpieczeństwa ekologicznego [w:] Szulczewski, A., red., Bezpieczeństwo państw Europy Środkowo-Wschodniej w kontekście zagrożeń ekologicznych, Słupsk: Fundacja Pro Pomerania. Sommer, H., Zakrzewski, G. (2017). Zastosowanie piramidy Mastowa w ekologii informacjiprzyczynek do dyskusji [w:] Materska, K., Taraszkiewicz, B., red., Ekologia informacji a zasoby informacyjne $w$ bibliotekach $i$ cyberprzestrzeni. Słupsk: Biblioteka Uczelniana Akademii Pomorskiej.

Sommer, H., Zakrzewski, G. (2017a). Założenia dla edukacji ekologicznej czy bezpieczeństwa ekologicznego. „Humanities and Social Sciences”, Vol. XXII, 24 (3/2017) [Access: 08.04.2020]. Access on the internet: http://doi.prz.edu.pl/pl/publ/einh/344.

Sommer, H., Zakrzewski, G. (2018). Zarzadzanie w działach związanych zobronnościa państwa wedtug opinii studentów bezpieczeństwa. „Humanities and Social Sciences”, Vol. XXIII, 25 (3/2018) [Access: 8.04.2020]. Access on the internet: http://doi.prz.edu.pl/pl/pdf/einh/424.

DOI: $10.7862 /$ rz.2020.hss.48

The text was submitted to the editorial office: June 2020.

The text was accepted for publication: December 2020. 
